Int. J. Morphol.,

33(2):586-593, 2015.

\title{
Micro Hardness of Dental Tissues Influenced by Administration of Aspirin During Pregnancy
}

\author{
Microdureza de los tejidos dentales influenciada por la administración de aspirina durante el embarazo
}

\author{
Shakila Nazir*; Ashraf Ali** \& Shoaib Zaidi***
}

SHAKILA, N.; ALI, A. \& ZAIDI, S. Micro hardness of dental tissues influenced by administration of aspirin during pregnancy. Int. J. Morphol., 33(2):586-593, 2015.

SUMMARY: The study is associated with the effect of aspirin (Acetyl Salicylic Acid) on the microhardness of mineralized tissues of the offspring's teeth, in response to the ingestion of the drug during pregnancy. Aspirin is a widely used analgesic and antipyretic medicine, for symptomatic treatment. Misuse of this drug during pregnancy may instigate developmental defects in offspring. An experimental control study was designed, in which female rabbits were taken as representative mammalian models and treated with aspirin during pregnancy. Their offspring's teeth were used to assess the microhardness of dental tissues. The rabbits were alienated into two groups, treated and control, consisting of seven rabbits in each set $(n=7)$. Microhardness was evaluated in three types of the sample teeth. The total number of teeth examined were, $2 \times 7 \times 12=168$ samples. Vicker's Hardness degree values were measured and recorded vis-à-vis ( $50 \mathrm{~g}$ for $15 \mathrm{~s}$ with 3 indentations per specimen on enamel and dentine separately). The range of hardness obtained was statistically analyzed and the Student's t-tests was applied, with the aid of SPSS version 20. The P-values for both enamel and dentine from maxillary incisors and molars were less than 0.05. The same trend was observed in the mandibular teeth. However, a teratogenicity of Acetyl Salicylic Acid was pragmatic in the recent in vivo studies. Based on the analysis, it was evident that the aspirin administration could produce negative effects leading to reduction in the microhardness of dental tissues of the offsprings.

KEY WORDS: Dentition; Aspirin; Female rabbits; Teratogenic effect; Microhardness.

\section{INTRODUCTION}

Dental enamel is the hardest tissue in the human body and is directly responsible for dental function (Xie et al., 2009). It is the most mineralized tissue of human body. Its composition is $96 \%$ inorganic material and $4 \%$ organic material and water (Gutierrez-Salazar \& Reyes-Gasga, 2003). Developing body tissues may be effected by certain drugs, if given during pregnancy. Oral and dental structures are frequently the sites of adverse drug reactions (Seymour \& Rudralingham, 2008). Almost every pregnant woman is exposed to some type of medication during pregnancy (Buhimschi \& Weiner, 2009). It was also reported that drugs or physical agents can adversely affect the human teeth during their embryonic development and after their eruption into the oral cavity (Billings et al., 2004). Also, many drugs, both prescription and illegal, can cause tooth damage. It was estimated that, intake of a particular medicine can damage teeth of about $40 \%$ of people. Fluoride strengthens the teeth but excessive fluoride can cause fluorosis. Aspirin chewing can directly damage the tooth enamel, as aspirin is acidic, some asthma drugs are highly acidic and can dissolve tooth enamel (Better Health Channel, 2013). Routinely prescribed medications do have potential to cause various side effects on the dental hard tissue, causing physical damage to the tooth structure (Mehrotra et al., 2011). As known, a direct relation exists between the values of hardness and the percentage of mineral volume (Arends \& ten Bosch, 1992). The differences in hardness of enamel can be associated to the mineral content in enamel (Kodaska \& Debari, 1982). Prior studies demonstrate that the hardness of enamel and dentin has been measured on ground sections of the teeth (Fuentes et al., 2003; Ferreira et al., 2006). Available published data revealed the mean Knoop Hardness Number (KHN) values of superficial and deep dentin at $50 \mathrm{~g}$ load as, 73.75 and 64.75 respectively (Fuentes et al.). The baseline Vickers micro hardness values of enamel appeared between 332.1 and 316.1 (Ferreira et al.). According to another study,

\footnotetext{
* Professor of Oral Biology, Baqai Dental College, Baqai Medical University, Karachi, Pakistan.

** Professor and Chairman, Department of Materials Engineering, NED University of Engineering and Technology, Karachi, Pakistan.

${ }^{* * * *}$ Professor and Dean, School of Science and Engineering, Habib University, Karachi, Pakistan.
} 
the hardness values for sound enamel was reported as, VHN 268-375, using Vickers diamond at a load of $25 \mathrm{~g}$, for $15 \mathrm{~s}$ (Gutiérrez-Salazar \& Reyes-Gasga, 2001). The highest mean Vickers hardness numbers VHN, reported by Salama (2004), for sound enamel was, 274.247+10.927 (X \pm SD). Hardness of human teeth, both in enamel and dentin, has been measured at different sites using a Vicker's diamond. We could find the range of hardness values from 270 to 360 , the VHN for enamel and 50 to 60 , the VHN for dentin (Gutiérrez-Salazar \& Reyes-Gasga, 2003). Prior studies also revealed that the Enamel was always more radio dense than dentin and also presented higher KHN p=0.001 (Fonseca et al., 2008).

\section{MATERIAL AND METHOD}

The present in vivo study was designed using fourteen adult female rabbits as an animal model weighing between 1.5 to $2.0 \mathrm{~kg}$ each. They were estranged into two groups, a treated and the other one control, having seven rabbits in each set $(n=7)$. One group was treated with the aspirin (Disprin ${ }^{\circledR} 300 \mathrm{mg}$ Reg. No. 000152), while the second group was taken as control. One tablet of Disprin was dissolved in $25 \mathrm{ml}$ of the distilled water to prepare the medicine. One $\mathrm{ml}$ $(8 \mathrm{mg} / \mathrm{kg})$ of that preparation was administered orally, twice a week to the female rabbits of the investigational group. Dose of the drug was calculated according to the body weight of the animal, based on the Clark's rule (Koren, 2007), i.e.

\section{Dose $=$ Adult dose $\mathrm{x}($ Weight $\mathrm{Kg} / 70)$}

Subjects of the trial group were kept with the equal number of their male partners at their individual locations. Credentials of the subjects was done by means of colored metallic wires, strung with beads wrapped around the hind leg of the animal. Color of the wire certained the splinter group and the number of beads indicated number of the subject in a particular group. A predesigned proforma was used to sustain the record regarding the details of drug administration specified to a particular animal, also, any toxicity (diarrhea, ulceration, edema, hair loss or anorexia), if developed by the given drug. The medicine was administered according to the predetermined dose in expectancy of their offsprings. These offsprings were dilapidated for the research purpose and sacrificed at the age of three months to attain their upper and lower jaws. The jaws were then cleaned and checked for the eruption, status of teeth. Cadaver of the maxilla and mandible were sectioned and teeth were extracted from the jaws with the help of diverse instruments used in dentistry. Extracted teeth were then washed by the de-ionized or distilled water in a Dappen dish and conserved in $10 \%$ formalin in bottles, categorized with individual code numbers for each sculpt of the tooth. Three types of teeth, i.e. central incisors, first premolars and first molars of each quadrant from the maxillary and mandibular arches were incorporated in the study. The decisive factor for the inclusion of samples was the diversity of same number of subjects (belonging to three classes) with no perceptible defects. Twelve teeth were hence taken from each animal of investigation and control group, the total number of teeth (samples) included in the study were $(12 \times 7 \times 2) 168$. This inclusion criterion could possibly provide adequate information to portray a conclusion.

Code numbers of the teeth included in the study:

$$
\begin{aligned}
& {[101,106,109] \text { - Right maxillary arch. }} \\
& {[201,206,209] \text { - Left maxillary arch. }} \\
& {[301,307,309] \text { - Left mandibular arch. }} \\
& {[401,407,409] \text { - Right mandibular arch. }}
\end{aligned}
$$

Sample preparation for testing microhardness. Preparation of the samples was done by "Cold mounting", using Epoxy mount resin (Diglycidyl Ether Resin) and epoxy mount hardener (N-Aminoethylpiperazine). The resin and hardener, weighed in grams were put into the mould by the ratio of 10:3 to cure or harden at room temperature. Orientation of the sample tooth was kept vertical in the mould to be embedded in the material for easy access to enamel and dentine. The mounted specimen and size of the mould was according to the diameter/height i.e. $30 / 15 \mathrm{~mm}$. The mounting material was transparent, thus easy to identify and locate the dental tissues. The sample was moved to rest the probes on the tissues for measuring the microhardness.

Grinding. Grinding of the specimens was required before polishing. It was done after hardening of the sample, so for this purpose, waterproof emery papers having $\mathrm{SiC}$ (Silicon Carbide) particles of 180, 220, 320, 400, 600, 800 and 1000 grit size were used. In order to prevent the rocking during grinding and polishing, the edges of the mounted specimens were kept rounded to minimize damaging the resin. During that procedure, the specimens were ground progressively with water irrigation by means of the grinding machine (Model No. Maopao 260 E). To produce a reasonably flat surface, specimens were then washed with running water before polishing so as to eliminate the debris.

Polishing. The polishing of the specimens was carried out on the polishing machine (Model No. DUO 12 Benetec), by means of rotating wheels which were covered with a cloth impregnated by a fine abrasive compound, Alumina (Aluminum Oxide: $\mathrm{Al}_{2} \mathrm{O}_{3}$ ) suspension in $\mathrm{H}_{2} \mathrm{O}$ gradually with 5,1 and $0.05 \mu \mathrm{m}$. 
Micro Vickers hardness. Process of testing the hardness was done on Micro Vicker hardness testing machine (Model No.402 MVD), which is appropriate for determining the hardness of brittle materials, such as tooth structure. In this test a diamond shaped square-based pyramid of $136^{\circ}$ was pressed into the polished surface of the specimen, placed on the machine podium under a specific load of $50 \mathrm{~g}$ with the Dwell time of $15 \mathrm{~s}$. Surface of each sample received 3 indentations for the enamel as well as dentine (Figs. 1 to 6). The dimensions of the indent were noted and entered in the automated machine for the calculation of microhardness of the dental tissues. The calculation of the microhardness at each point was done based on the equation below (Avner, 2006).

$$
\mathrm{HV}=1.854 \mathrm{~L} / \mathrm{d}^{2}
$$

Where,

$\mathrm{L}=$ Denotes the applied load on indenter in $\mathrm{kg}$.

$\mathrm{d}=$ for, mean diagonal of indentation, in $\mathrm{mm}$.

$\mathrm{HV}=$ Vicker's microhardness degree $\left(\mathrm{kg} / \mathrm{mm}^{2}\right)$

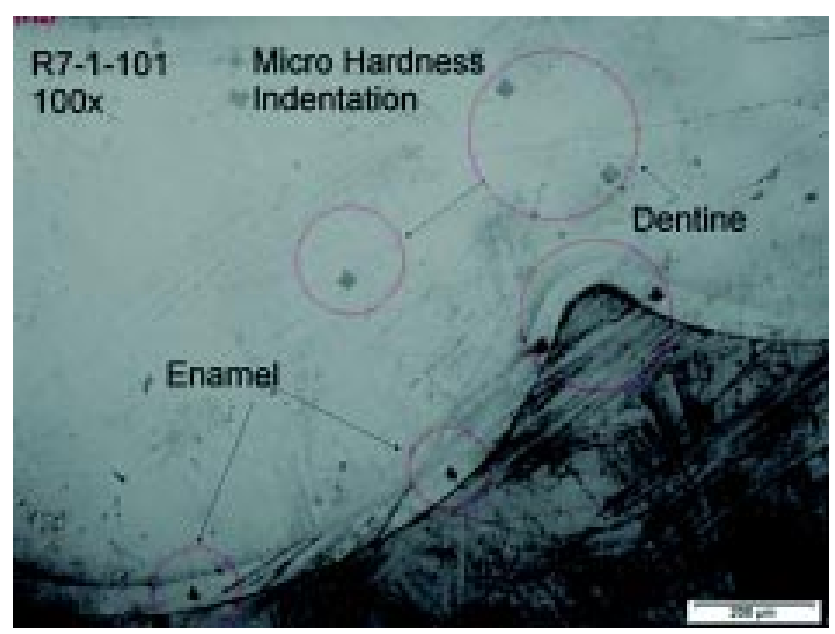

Fig. 1. Right maxillary central incisor.

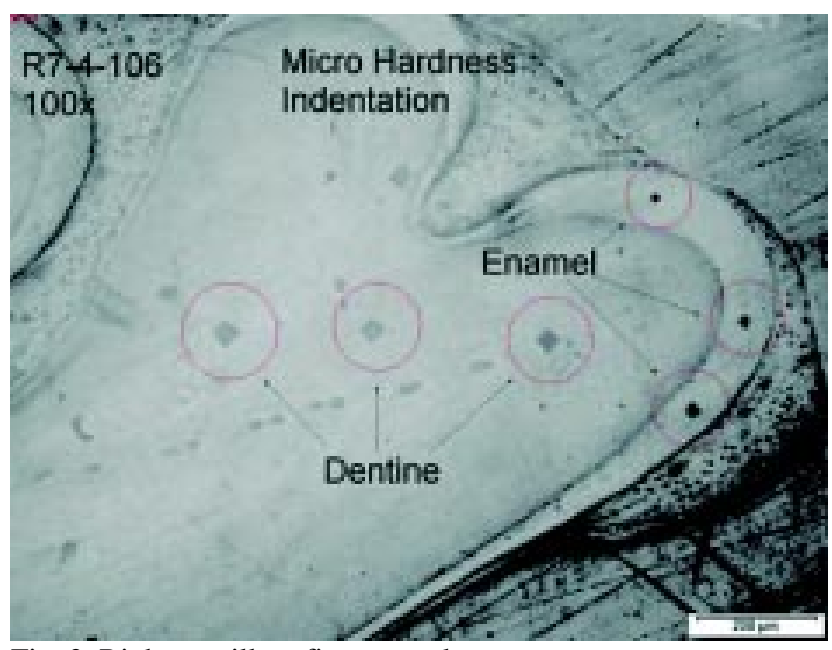

Fig. 2. Right maxillary first premolar.
Image analyser. The images were studied, with the aid of an optical microscope (Model No. MMD-GX 51 Olympus), to capture a high quality magnified image. Magnification levels include $50 \mathrm{X}, 100 \mathrm{X}, 500 \mathrm{X}$ and 1000 . Images of the testing samples were taken on $100 \mathrm{X}$ magnification.

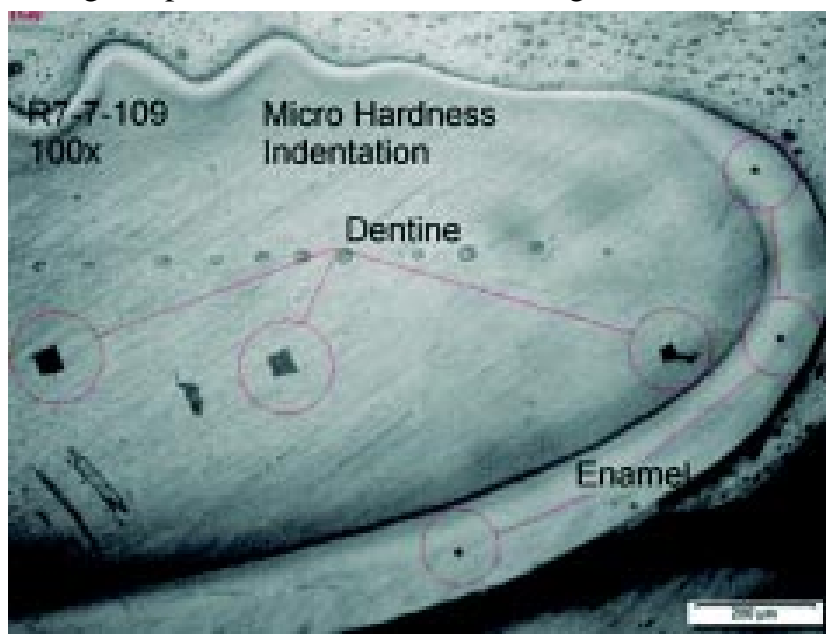

Fig. 3. Right maxillary first molar.

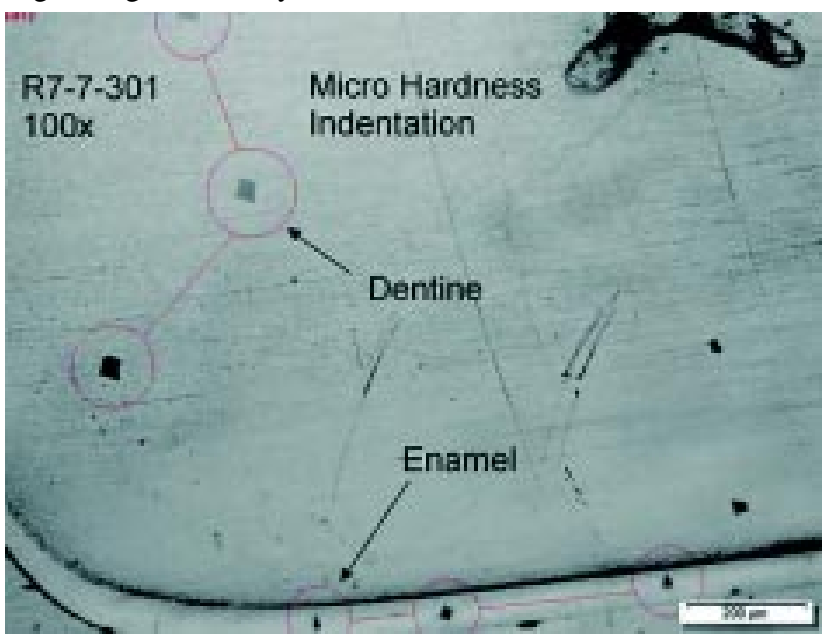

Fig. 4. Left mandibular incisor.

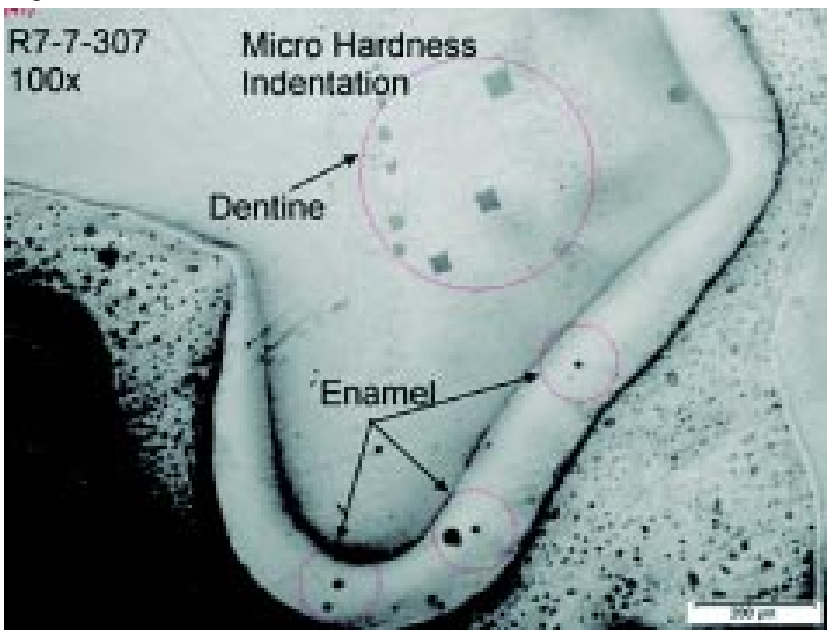

Fig. 5. Left mandibular first premolar. 


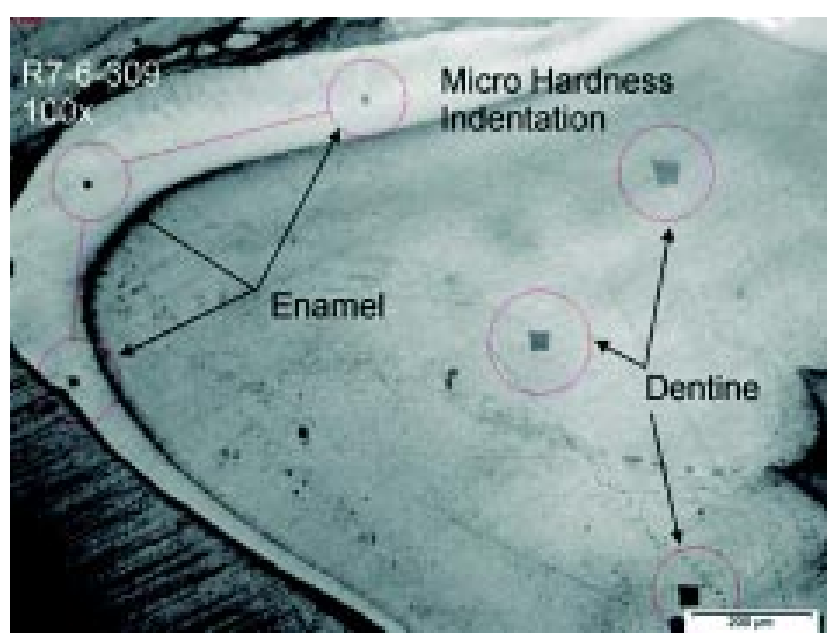

Fig. 6. Left mandibular first molar.

\section{RESULTS}

The range of microhardness values obtained in the present study, regarding both the mineralized dental tissues i.e. enamel and dentine in the investigational and control group of maxillary teeth is shown in (Table I), and those of mandibular teeth in (Table II). Vicker's hardness profile of enamel is expressed in (Fig. 7) and that of dentine in (Fig. 8). Comparison of the continuous data profile of the trial and control group was statistically analyzed, applying student's t-test with the aid of SPSS version 20. Statistical significance was recorded in terms of P-values, and a Pvalue $\leq 0.05$ was considered as statistically significant. The data analysis of tooth hardness, derived by descriptive statistical indicators, revealed the effect of aspirin on the hardness of enamel, in which Maxillary incisors, showing the P-values of 0.003 and $0.002<0.05$, maxillary first premolars appeared with a P-values $0.276>0.05$ and $0.006<0.05$ and the hardness of the first molars of both the right and left quadrants showed the P-values as, $0.001<0.05$ (Table I). Regarding the hardness of dentine, which is the second mineralized tissue underlying the superficial layer of enamel, the P-values of all the three types of teeth in both, right and the left quadrants appeared less than 0.05 i.e. Pvalues of incisors was 0.025 and 0.001 , the first premolars with 0.001 and 0.017 and those of first molars having 0.000 and 0.000 (Table I).

Vicker's micro hardness of enamel in mandibuar teeth revealed the $\mathrm{P}$-values of incisors as, 0.000 and $0.003<0.05$, for the first premolars with P-values of $0.069>0.05$ and $0.00<0.05$ and the first molars having 0.000 and $0.001<0.05$. Hardness of the dentine in the mandibular teeth showed the P-values of incisors as $0.000<0.05$ and 6.270 $>0.05$, similarly for first premolars the P-values were 0.124 and $0.486>0.05$ and the first molars appeared with 0.023 and $0.000<0.05$ (Table II).

Table I. Maxillary teeth. Vicker's micro hardness hardness (HV) degree $\left(\mathrm{kg} / \mathrm{mm}^{2}\right)$.

\begin{tabular}{lcccccc}
\hline \multirow{2}{*}{$\begin{array}{l}\text { Code \# } \\
\text { of Teeth }\end{array}$} & \multicolumn{3}{c}{ Enamel } & \multicolumn{3}{c}{ Dentine } \\
\cline { 2 - 7 } & $\mathbf{N}$ & $\mathbf{N}=\mathbf{7})$ Mean \pm SD & P-Value & $\mathbf{~}$ & $\mathbf{N}=\mathbf{7})$ Mean \pm SD & P-Value \\
\hline 101 & $242.788 \pm 17.965$ & $187.530 \pm 37.051$ & 0.003 & $61.382 \pm 6.595$ & $55.147 \pm 3.800$ & 0.025 \\
201 & $245.287 \pm 19.105$ & $187.262 \pm 37.525$ & 0.002 & $64.028 \pm 5.234$ & $55.055 \pm 3.483$ & 0.0013 \\
106 & $209.217 \pm 50.482$ & $196.732 \pm 16.689$ & 0.276 & $41.850 \pm 11.705$ & $37.487 \pm 6.452$ & 0.0013 \\
206 & $233.911 \pm 26.547$ & $198.381 \pm 17.775$ & 0.006 & $44.822 \pm 1.408$ & $37.788 \pm 6.863$ & 0.0174 \\
109 & $252.924 \pm 30.538$ & $176.654 \pm 41.797$ & 0.001 & $44.552 \pm 6.631$ & $32.037 \pm 4.622$ & 0.0007 \\
209 & $267.427 \pm 42.254$ & $178.451 \pm 42.521$ & 0.0010 & $37.805 \pm 6.774$ & $32.257 \pm 4.499$ & 0.000 \\
\hline
\end{tabular}

$\mathrm{N}=$ Control group, $\mathrm{T}=$ Treatment with Aspirin.

Table II. Mandibular teeth. Vicker's micro hardness hardness (HV) degree $\left(\mathrm{kg} / \mathrm{mm}^{2}\right)$

\begin{tabular}{|c|c|c|c|c|c|c|}
\hline \multirow{3}{*}{$\begin{array}{l}\text { Code \# } \\
\text { of Teeth }\end{array}$} & \multicolumn{3}{|c|}{ Enamel } & \multicolumn{3}{|c|}{ Dentine } \\
\hline & \multicolumn{2}{|c|}{$(n=7)$ Mean \pm SD } & \multirow{2}{*}{ P-Value } & \multicolumn{2}{|c|}{$(n=7)$ Mean \pm SD } & \multirow{2}{*}{ P-Value } \\
\hline & $\mathbf{N}$ & $\mathbf{T}$ & & $\mathbf{N}$ & $\mathbf{T}$ & \\
\hline 301 & $272.757 \pm 13.717$ & $198.371 \pm 37.834$ & 0.000 & $56.091 \pm 12.142$ & $12.1425 \pm 4.720$ & 0.000 \\
\hline 401 & $37.834 \pm 22.446$ & $197.091 \pm 37.315$ & 0.003 & $63.717 \pm 7.350$ & $43.950 \pm 5.891$ & 6.270 \\
\hline 307 & $214.784 \pm 37.841$ & $181.261 \pm 40.973$ & 0.069 & $39.934 \pm 9.015$ & $34.524 \pm 7.650$ & 0.124 \\
\hline 407 & $260.397 \pm 31.078$ & $181.352 \pm 41.480$ & 0.001 & $48.402 \pm 9.086$ & $47.920 \pm 34.991$ & 0.486 \\
\hline 309 & $254.634 \pm 18.857$ & $196.624 \pm 21.865$ & 0.000 & $41.454 \pm 5.769$ & $35.900 \pm 3.251$ & 0.023 \\
\hline 409 & $246.015 \pm 25.858$ & $197.500 \pm 20.921$ & 0.001 & $44.107 \pm 4.051$ & $36.185 \pm 2.784$ & 0.000 \\
\hline
\end{tabular}

$\mathrm{N}=$ Control group, $\mathrm{T}=$ Treatment with Aspirin. 


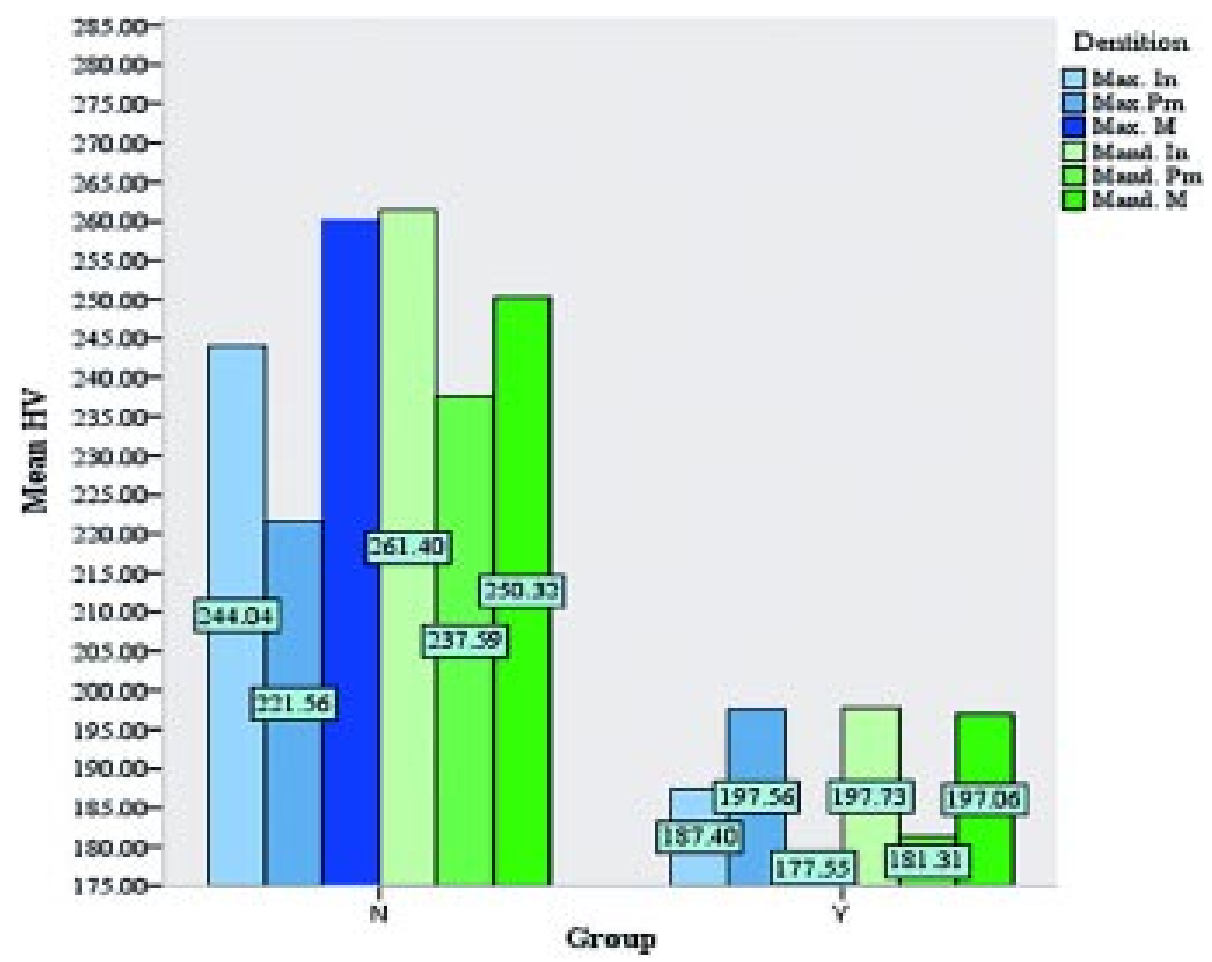

Fig. 7. Graphic representation of Vicker's Hardness profile of dental enamel.

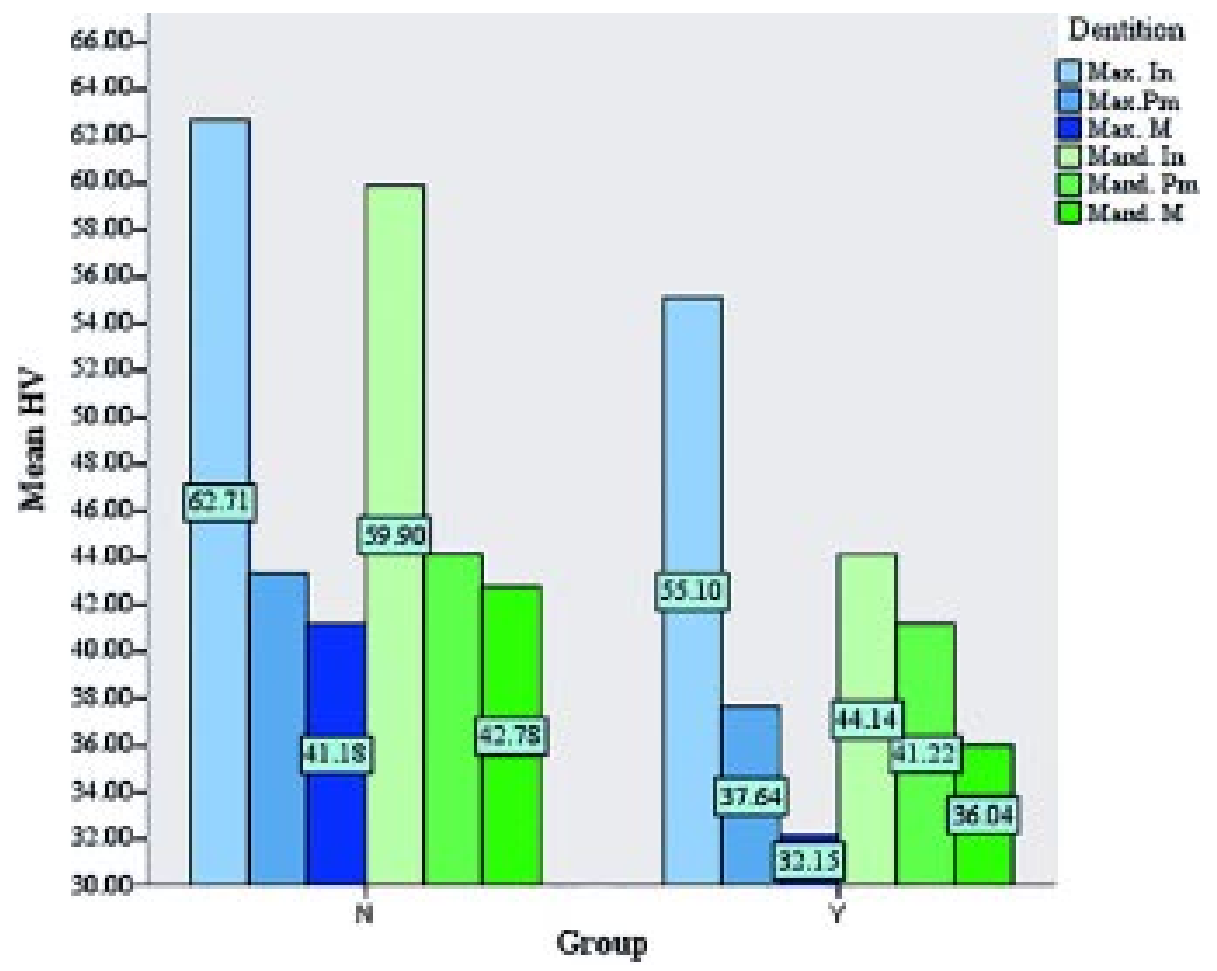

Fig. 8. Graphic representation of Vicker's Hardness profile of dental dentine. 


\section{DISCUSSION}

Conception of the mechanical properties of dentition is important to figure out, how the process of mastication is strewn if the microhardness of dental tissues is affected. Many drugs can have an adverse effect on teeth (Tredwin et al., 2005). The effect of in utero exposure of aspirin on the developing teeth was meticulously searched in the published literature. There is a lack of literature regarding the effect of aspirin on the microhardness of the dental tissues of the neonates, when the drug is used by the mother right through the pregnancy. Aspirin is capable of causing serious damage to hard and soft teeth tissues alike. Dentists however noticed the defects on the surface of teeth, that came in direct contact with the aspirin were damaged the most (Grace et al., 2004). Prior studies also revealed the local erosive effects of aspirinchewing on the human enamel (Better Health Channel; Grace et al.). The influence of various bleaching systems on microhardness of enamel and dentin was also evaluated which was significantly reduced in both enamel and dentin (Attin $e t$ al., 2005). However, the published information cannot be compared with the present study, where aspirin was administered systemically during pregnancy, which affected the microhardness of dental tissues in neonates. Hardness measurements were performed on experimental cross-sections of the teeth in a prior study, showing the total average hardness of $73.17 \mathrm{HV}$ and standard deviation of $55.68 \mathrm{HV}$, but it did not refer to the dental tissue on which the test was performed, also, it was not related to any external stimuli (Gnjato, 2010). Hardness measurements of mature, sound premolars freshly extracted for orthodontic reasons was reported in the range from 270 to $360 \mathrm{VHN}$ for enamel and 50 to $60 \mathrm{VHN}$ for dentin (Gutiérrez-Salazar \& Reyes-Gasga, 2003). Another report regarding the baseline Vickers microhardness values of enamel appeared between 332.1 and 316.1 (11) (Ferreira et al., 2006) . According to the former investigations and the published data, the Vickers microhardness values of the sound enamel and dentin was almost the same as discussed in the present study (Gutiérrez-Salazar \& Reyes-Gasga, 2003, 2001; Fuentes et al.; Ferreira et al.).

Findings of the present study demonstrated that the Vickers microhardness values (HV) in the enamel of maxillary teeth was distinctly abridged in incisors, premolars and molars from 244.04 to $187.40,221.56$ to 197.56 and 260.00 to 177.55 respectively (Fig. 7). Microhardness of enamel in mandibular incisors, premolars and molars dropped from 261.40 to $197.73,237.59$ to 181.31 and 250.32 to 197.06 respectively (Fig. 7). The observations regarding the consequences on enamel are consistent with the outcome of the drug's effect on the hardness of dentin. In the maxillary incisors, premolars and molars, comparing the control with treated group, changed from 62.71 to 55.10 , from 43.00 to 37,64 and from 41.18 to 32.15, respectively (Fig. 8). Taking into account, the microhardness of dentin in mandibular incisors, premolars and molars, also dipping from 59.90 to $44.14,44.00$ to 41.22 and 42.78 to 36.04 , respectively (Fig. 8). Ranking the hardness for individual teeth in light of the collected data, the microhardness of incisors and mandibular molars were found to be the most effected teeth. A dose related effect was evident, though a significant differences in the hardness existed in enamel, the same trend was also observed in the dentin. There are few reports in the literature about fluoride, increasing the microhardness of the enamel (Samuel \& Rubinstein, 2001), also influenced the dentine (Vieira et al., 2005). According to the available published data from the above mentioned reports, the systematic effect of the drug on the tooth hardness was not explored, so it could not be compared with the current study. In the contemporary study, the medicine was administered systemically to evaluate the effect on the dental tissues of the neonates. Review of the literature indicated the potential association of NSAIDs with developmental toxicity of diaphragmatic hernia, midline defect and ventricular septal defects in rats and rabbits (Tassinari et al., 2003; Gupta et al., 2003; Cook et al., 2003). The rate of perinatal mortality was reported providing the information of high-risk pregnancies, where aspirin treatment seemed to have a small but significant effect on reducing the rate of preterm deliveries, but did not reduce the rate of perinatal death (Kozer et al., 2003). Again these reports were not analogous with the pooled results of the recent study. In the academic literature, there are no such studies regarding the effect of systemically administered aspirin on the dental tissues of the newborns. It would thus be difficult to establish a comparison with the published reports, since this type of research has not been done in the times of yore. In this manuscript, based on the toil, it is clear that the drug administration strategies could produce negative effects leading to the reduction in microhardness of dental tissues in neonates. Most of the drugs can cross the placenta, even a single intra uterine exposure to a drug can affect the fetal structures undergoing rapid development (Koren).

\section{CONCLUSION}

A comprehensive analysis of the dose related effect was evaluated in the existing study. Dental tissues being susceptible to peripheral stimuli or any teratogenic consequence, thus increasing the possibility to cause the developmental anomalies in babies of the user females. Perception of adverse drug-induced oral effects is imperative, which helps the professionals to prescribe them having cautiously considered the undesirable special effects that may occur as a result and perk up patient acquiescence. 
ANNEXURE. The dental formula of the rabbit teeth by Rouge (2002) is; I-2/1: C-0/0: Pm-3/2: M-3/3 ( $\mathrm{x}^{2}=28$ total teeth). Rabbit's teeth are recognized with their meticulous cryptogram numbers by David Crossley (http:// www.vet.ed.ac.uk/clive/cal/Dentistry/website/basics/triadan/ other.html). They are as follows:

101- Right maxillary central Incisor.

102- Right maxillary lateral Incisor.

106- Right maxillary first Premolar.

107- Right maxillary second Premolar.

108- Right maxillary third Premolar.

109- Right maxillary first Molar.

110- Right maxillary second Molar.

111- Right maxillary third Molar.

201- Left maxillary central Incisor.

202- Left maxillary lateral Incisor.

206- Left maxillary first Premolar.

207- Left maxillary second Premolar.

208- Left maxillary third Premolar.

209- Left maxillary first Molar.

210- Left maxillary second Molar.

211- Left maxillary third Molar.

301- Left mandibular Incisor.
307- Left mandibular first Premolar.

308- Left mandibular second Premolar.

309- Left mandibular first Molar.

310- Left mandibular second Molar.

311- Left mandibular third Molar.

401- Right mandibular Incisor.

407- Right mandibular first Premolar.

408- Right mandibular second Premolar.

409- Right mandibular first Molar.

410- Right mandibular second Molar.

411- Right mandibular third Molar.

\section{ACKNOWLEDGEMENTS}

We acknowledge the technical help and faculty support, received from the Materials Engineering department, NED University of Engineering and Technology, Karachi. Authors appreciate the help and guidance rendered by Dr. Sarosh Hashmat Lodi, Dean (Civil engineering and architecture) NED University of Engineering and Technology, Karachi.

SHAKILA, N.; ALI, A. \& ZAIDI, S. Microdureza de los tejidos dentales influenciada por la administración de aspirina durante el embarazo. Int. J. Morphol., 33(2):586-593, 2015.

RESUMEN: El estudio asocia el efecto de la aspirina (ácido acetil salicílico) sobre la microdureza de los tejidos mineralizados de los dientes de crías, en respuesta a la ingesta del fármaco durante la preñez. La aspirina es un analgésico y antipirético ampliamente utilizado para el tratamiento sintomático. El mal uso de esta droga durante la preñez puede inducir defectos en el desarrollo de las crías. Se diseñó un estudio experimental de control, en el que se tomaron conejas como modelos de mamíferos representativos y fueron tratados con aspirina durante la preñez. Los dientes de sus crías fueron utilizados para evaluar la microdureza de los tejidos dentales. Los animales fueron distribuidos en dos grupos, tratados y control, con siete animales en cada grupo $(\mathrm{n}=7)$. La microdureza se evaluó en tres tipos de dientes de la muestra. El número total de dientes examinados fueron 168 (2x7x12). Se midieron y registraron valores del grado de dureza Vickers vis-à-vis ( $50 \mathrm{~g}$ por $15 \mathrm{~s}$ con 3 indentaciones por especimen sobre el esmalte y la dentina por separado). Se analizó estadísticamente la gama de dureza obtenida y se aplicaron pruebas t de Student con la ayuda del programa SPSS versión 20. Los valores de p para el esmalte y la dentina de los incisivos maxilares y molares fueron menores a 0,05 . Se observó la misma tendencia en los dientes mandibulares. Sin embargo, teratogenicidad producto del ácido acetil salicílico se encontró en recientes estudios in vivo. De acuerdo al análisis de los resultados, se evidenció que la administración de aspirina provocó efectos negativos que determinaron la reducción de la microdureza de los tejidos dentales de las crías.

PALABRAS CLAVE: Dentición; Aspirina; Conejos; Efecto teratogénico; Microdureza.

\section{REFERENCES}

Arends, J. \& ten Bosch, J. J. Demineralization and remineralization evaluation techniques. J. Dent. Res., 71(1):924-33, 1992.

Attin, T.; Vollmer, D.; Wiegand, A.; Attin, R. \& Betke, H. Subsurface microhardness of enamel and dentin after different external bleaching procedures. Am. J. Dent., 18(1):8-12, 2005.
Avner, S. H. Tools of the Metallurgist. In: Avner, S. H. (Ed.). Introduction to Physical Metallurgy. 22nd ed. New York, McGraw-Hill, 2006. pp.1-63.

Billings, R. J.; Berkowitz, R. J. \& Watson, G. Teeth. Pediatrics, 113(4 Suppl.):1120-7, 2004. 
Better Health Channel. Teeth and drug use [website on the Internet]. 2013. Available from: http://www.betterhealth.vic.gov.au/ bhcv2/bhcarticles.nsf/pages/Teeth_and_drug_use

Buhimschi, C. S. \& Weiner, C. P. Medications in pregnancy and lactation: part 1. Teratology. Obstet. Gynecol., 113(1):166-88, 2009 .

Cook, J. C.; Jacobson, C. F.; Gao, F.; Tassinari, M. S.; Hurtt, M. E. \& DeSesso, J. M. Analysis of the nonsteroidal antiinflammatory drug literature for potential developmental toxicity in rats and rabbits. Birth Defects Res. B Dev. Reprod. Toxicol., 68(1):5-26, 2003.

Ferreira, I. A.; Lopes, G. C.; Cardoso Vieira, L. C. \& Araujo, E. Effect of hydrogen-peroxide-based home bleaching agents on enamel hardness. Braz. J. Oral Sci., 5(18):1090-3, 2006.

Fonseca, R. B.; Haiter-Neto, F.; Carlo, H. L.; Soares, C. J.; Sinhoreti, M. A.; Puppin-Rontani, R. M. \& Correr-Sobrinho, L. Radiodensity and hardness of enamel and dentin of human and bovine teeth, varying bovine teeth age. Arch. Oral Biol., 53(11):1023-9, 2008.

Fuentes, V.; Toledano, M.; Osorio, R. \& Carvalho, R. M. Microhardness of superficial and deep sound human dentin. $J$. Biomed. Mater Res., 66(4):850-3, 2003.

Gnjato, S. Addition to the methodology of research into permanent teeth hardness. Arch. Biol. Sci. (Belgrad.), 62(3):739-46, 2010.

Grace, E. G.; Sarlani, E. \& Kaplan, S. Tooth erosion caused by chewing aspirin. J. Am. Dent. Assoc., 135(7):911-4, 2004.

Gupta, U.; Cook, J.C.; Tassinari, M.S.; Hurtt, M.E. Comparison of developmental toxicology of aspirin (acetylsalicylic acid) in rats using selected dosing paradigms. Birth Defects Res. B. Dev. Reprod. Toxicol., 68(1):27-37, 2003.

Gutierrez-Salazar, M. P. \& Reyes-Gasga, J. Enamel hardness and caries susceptibility in human teeth. Rev. Latinoam. Metal. Mater., 21(2):36-40, 2001.

Gutiérrez-Salazar, M. P. \& Reyes-Gasga, J. Microhardness and chemical composition of human tooth. Mater. Res., 6(3):36773,2003

Kodaska, T. \& Debari, K. Structure, microhardness and calcification values of enamel tufts in human teeth. Bull. Tokyo Dent. Coll., 23(4):227-38, 1982.

Koren, G. Special Aspects of Perinatal \& Pediatric Pharmacology. In: Katzung, B. G. (Eds.). Basic and Clinical Pharmacology. 10th ed. New York, McGraw-Hill Lange, 2007. pp.971-82.

Kozer, F.; Costei, A.M.; Boskovic, R.; Nulman, I.; Nikfar, S.; Koren. G. Effects of aspirin consumption during pregnancy on pregnancy outcomes: meta-analysis. Birth Defects Res. B Dev. Reprod. Toxicol., 68(1):70-84, 2003.
Mehrotra, V.; Devi, P. \& Bhovi, T. V. Drug induced disorders of teeth- an eye opener. Bangladesh Res. Publ. J., 5(1):68-77, 2011.

Rouge, M. Dental Anatomy of Rabbits. In: Bowen, R. A.; Austgen, L. \& Rouge, M. (Eds.). Pathophysiology of the Digestive System [homepage]. Fort Collins, Colorado State University, 2002. Available from: http://www.vivo.colostate.edu/hbooks/ pathphys/digestion/pregastric/rabbitpage.html

Salama, F. S. Microhardness and mineral contents of sound and carious human primary teeth. J. Pak., Dent. Assoc., 13(2):725, 2004.

Seymour, R. A. \& Rudralingham, M. Oral and dental adverse drug reactions. Periodontol., 46:9-26, 2008.

Samuel, S. M. \& Rubinstein, C. Microhardness of enamel restored with fluoride and non-fluoride releasing dental materials. Braz. Dent. J., 12(1):35-8, 2001.

Tassinari, M. S.; Cook, J. C. \& Hurtt, M. E. NSAIDs and developmental toxicity. Birth Defects Res. B Dev. Reprod., 68(1):3-4, 2003.

Tredwin, C. J.; Scully, C. \& Bagan-Sebastian, J. V. Drug-induced disorders of teeth. J. Dent. Res., 84(7):596-602, 2005.

Vieira, A.; Hancock, R.; Dumitriu, M.; Schwartz, M.; Limeback, H. \& Grynpas, M. How does fluoride affect dentin microhardness and mineralization? J. Dent. Res., 84(10):9517, 2005.

Xie, Z.; Swain, M. V. \& Hoffman, M. J. Structural integrity of enamel: experimental and modeling. J. Dent. Res., 88(6):52933, 2009

\section{Correspondence to: \\ Dr. Shakila Nazir \\ Professor of Oral Biology \\ Baqai Dental College \\ Baqai Medical University \\ 51-Deh Tor near toll plaza, super highway Karachi \\ PAKISTAN}

\section{Email: shakila.nazir@gmail.com}

Received: 27-11-2014

Accepted: 17-03-2015 